\title{
THE CORRELATION OF TELEVISION SHOW AND BULLYING BEHAVIOR IN HIGH SCHOOL OF MAHA PUTRA IN MAKASSAR
}

\author{
Suryani $^{1}$, Andriani ${ }^{2}$, Rosyidah Arafat ${ }^{3}$ \\ 1,2,3 Nursing Study Program, Universitas Hasanuddin Makassar \\ email: suryani.abidin81@gmail.com
}

\begin{abstract}
Introduction: Bullying is an experience that occurs when the helplessness persecuted by the others behaviour and afraid of the repected bad behaviour and ill do it is repeated. One of causes bullying behavior is a television show, this can occur because television show that is presented is very diverse, so that school children is free to watch their favorite television show. This study aimed to determine the relationship between television show with bullying behavior in student of class XI and XII in SMA Maha Putra Makassar. Methode: This study using cross sectional method. The total study populations 130 and samples are 98 respondents with purposive sampling technique. Data analyzed were using the Chi-Square. Result: In this study showed that there is no relationship between television show with bullying behavior in student of class XI and XII in Maha Putra Senior High School Makassar. Conclusions: Level bullying dominant is low level with the bullying often is verbal bullying, and program often that watched is soap opera. Therefore, they are expected to do more introduce of bullying to students.
\end{abstract}

Key words : Show, Bullying Behavior, student of class XI and XII

\section{PENDAHULUAN}

Kasus-kasus yang marak terjadi pada anak-anak usia sekolah saat ini sungguh memperihatinkan bagi pendidik dan orang tua. Sekolah yang seharusnya menjadi tempat yang aman bagi anak untuk menuntut ilmu serta membantu membentuk karakter pribadi yang positif justru menjadi tempat tumbuh suburnya praktek-praktek bullying (Usman, 2013). Seorang psikolog Andrew Mellor mengemukakan bahwa bullying merupakan pengalaman yang terjadi ketika seseorang yang tidak berdaya merasa teraniaya oleh tindakan orang lain dan takut apabila perilaku buruk tersebut terulang dan ia tidak dapat mencegahnya, serta perlakuan buruk tersebut dilakukan secara berulang (Komisi Perlindungan Anak Indonesia, 2014). Ada 5 bentuk bullying, diantaranya: Kontak fisik langsung, kontak verbal langsung, perilaku nonverbal langsung, perilaku nonverbal tidak langsung, dan pelecehan seksual (Astuti \& Resminingsih, 2010).

Hasil kajian Konsorsium Nasional Pengembangan Sekolah Karakter (KNPSK) menunjukkan hampir setiap sekolah di Indonesia terdapat kejadian bullying (Rini, 2014). Berdasarkan kajian tersebut ketua KNPSK, Susanto menyatakan bahwa Indonesia termasuk kategori darurat bullying (Rini, 2014). Data menunjukkan jumlah anak sebagai pelaku bullying di sekolah mengalami peningkatan darai 67 kasus di tahun 2015 (Hazliansyah, 2015). Sekitar $84 \%$ anak di Indonesia mengalami kekerasan di sekolah, angka terssebut lebih tinggi dari tren di kawasan Asia yakni $70 \%$, hal ini merupakan hasil riset di 5 negara Asia yang salah satunya adalah Indonesia yang dilakukan oleh Plan International dan International Center for Research on Women (ICRW) (KPAI, 2016). Sementara di tahun 2016 pengaduan kekerasan dan keterlibatan anak terhadap 
masalah hukum mengalami kenaikan 15\% menurut Komisi Perlindungan Anak Indonesia (KPAI) yang total pengaduannya mencapai 645 laporan (Hamdi, 2016). Berdasarkan data Badan Pemberdayaan Perempuan dan Perlindungan Anak (BPPPA) Sulawesi Selatan, setidaknya terdapat 315 kasus kekerasan seksual pada anak sepanjang tahun 2015 dan pada tahun 2016 hingga bulan Mei terdapat 14 kasus kekerasan pada anak yang dilaporkan pada Pusat Pelayanan Terpadu Pemberdayaan Perempuan dan Anak (P2TP2A) Provinsi Sulawesi Selatan, mumlah tersebut belum termasuk laporan kasus pada P2TP2A kabupaten dan kota (Nugraha, 2016).

Tingkat kekerasan di Sekolah Menengah Atas (SMA) lebih tinggi dibandingkan dengan yang terjadi di Sekolah Tingkat Lanjutan Pertama (SLTP). Hal terseubt berdasarkan penelitian yang dilakukan oleh Yayasan Semai Jiwa Amini pada tahun 2008 tentang kekerasan bullying di Jogjakarta, Surabaya, dan Jakarta yang terdapat dalam Nurhayanti, Novotasari, \& Natalia (2013), dimana jumlah ditingkat SMA sebesar $67,9 \%$ dan $66,1 \%$ ditingkat SLTP. Hal ini dikarenakan masa SMA merupakan masa pencarian identitas diri yang cenderung mengadopsi nilai kelompok dan lingkungan serta pada masa ini remaja memiliki egosentrisme yang tinggi (Supartini, 2004; Usman, 2013).

Pelrilaku bullying bisa terjadi dikarenakan pola asuh orang tua yang terlalu permisif atau terlalu keras, kurangnya pengawasan dari orang tua, suka bergaul pada anak yang biasa melakukan bullying, pihak sekolah yang tidak menaruh perhatian pada tindakan bullying, banyak contoh perilaku bullying yang biasa disaksikan di televisi ataupun video game, pergalulan yang salah, iklim sekolah dan teman sebaya (Priyatna, 2010; Usman, 2013). Salah satu penyebab perilaku bullying ialah tayangan televisi, hal ini dibuktikan oleh penelitian Arifinda \& Hastuti
(2016) yang menunjukkan bahwa lama menonton televisi, preferensi menonton televisi, preferensi mebngakses muatan kekerasan, dan peniruan muatan kekerasan memiliki hubungan positif dengan perilaku bullying. Hal tersebut dapat terjadi karena tayangan televisi yang disajikan sudah sangat beragam dengan stasiun televisi yang juga sudah cukup banyak, sehingga anak sekolah sudah bebas menyaksikan siaran televisi yang mereka sukai.

Seluruh program acara yang ditayangkan untuk semua stasiun televisi nasional totalnya adalah 9.000-an program setiap bulannya, dai program tersebut program acara televisi yang memiliki kualitas terendah berdasarkan hasil survei Indeks Kualitas Program Siaran Televisi Komisi Penyiaran Indonesia (KPI) ialah program acara infotainment dengan nilai 2,34 dan pogram acara sinetron dengan nilai 2,51 darai standar kualitas KPI yaitu minimal 4,0 (KPI, 2015).

Seorang anak atau remaja dapat melakukan perilaku bullying akibat dari menonton tayangan televisi karena proses melihat tayangan misalnya kekerasan dan hal yang dilihat akan terekam di memori jangka pendek yang kemudian akan terekam di memori jangka panjang jika sering terpapar serta memeri tersebut akan terbuka ketika dihadapkan pada kondisi yang sama dengan yang pernah ditonton (Sherwood, 2013).

Ketika seseorang atau lebih melakukan perilaku bullying, akan menimbulkan dampak yang tidak bisa dianggap remehsebagaimana menurut Victorian Departement of Education and Early Chilhood Development, dampak bullying dapat dirasakan oleh pelaku, seperti cenderung berperilaku agresif dan terlibat dalam gank serta aktivitas kenakalan yang lain. Sedangkan dampak yang dirasakan oleh korban bullying ialah memiliki masalah emosi, harga diri rendah, merasa tertekan, suka menyendiri serta merasa tidak aman (KPAI, 2014), sebagai contoh 
seperti yang dikemukakan dalam penelitian Pambudhi \& Suroso (2015) bahwa seorang santri putri menunjukkan kecemasannya dengan mendiami dan berusaha menghindari pelaku bullying. Dampak perilaku bullying tidak hanya dirasakan oleh pelaku dan korban, tapi orang yang menjadi saksi saat perilaku bullying terjadi pun bisa merasakan dampaknya, seperti merasa ketakutan akan menjadi korban bullying selanjutnya (KPAI, 2014).

\section{METODE}

Variabel independent pada penelitian ini adalah tayangan televisi sedangkan variabel dependent adalah perilaku bullying. Responden dalam penelitian ini adalah siswa kelas XI dan XII di SMA Maha Putra Makassar. Pengambilan sampel menggunakan tekhnik purposive sampling. Metode penelitian menggunakan pendekatan cross sectional yaitu dengan cara setiap siswa mengisi kuesioner yang dibagikan tentang tayangan televisi dan perilaku bullying. Jumlah responden dalam penelitian ini adalah 98 responden. Kuesioner pada penelitian ini terdiri atas dua yaitu kuesioner tayangan televisi dan perilaku bullying. Kuesioner tayangan televisi terdiri dari 8 pertanyaan tertutup dan 5 pertanyaan terbuka. Kuesioner perilaku bullying terdiri dari 16 pertanyaan tertutup dengan skala likert. Pada setiap pertanyaan subjek diminta memilih satu jawaban dari 4 pilihan yang disediakan yaitu sangat sering diberi skor 3, sering diberi skor 2, jarang diberi skor 1 dan tidak pernah diberi skor 0. Pada tahap pengambilan data, peneliti didampingi seorang guru Bimbingan Konseling, kuesioner tersebut diisi di tempat dan tidak diperkenankan untuk di bawa pulang ke rumah. Variabel tayangan televisi memiliki skala ukur nominal dan veriabel perilaku bullying memiliki skala ukur ordinal yakni tinggi apabia memiliki skor $\geq 32$, sedang apabila memiliki skor 17-31, rendah apabila memiliki skor $<17$. Analisa data yang digunakan adalah analisa univariat yang digunakan untuk mengetahui distribusi frekuensi dari masingmasing variabel, sedangkan analisa bivariat menggunakan uji statistik chi square untuk mengetahui apakah terdapat hubungan antara tayangan televisi dengan perilaku bullying pada siswa kelas XI dan XII di SMA Maha Putra Makassar.

\section{HASIL}

\section{A. Analisi Univariat}

1. Gambaran perilaku bullying pada siswa kelas XI dan XII SMA Maha Putra Makassar

\begin{tabular}{lcc}
\hline & Frekuensi (f) & Persentasi (\%) \\
\hline Tinggi & 2 & 2,0 \\
Sedang & 4 & 4,1 \\
Rendah & 92 & 93,9 \\
\hline \multicolumn{1}{c}{ Total } & 98 & 100 \\
\hline
\end{tabular}

Tabel 1. Distribusi frekuensi tingkat perilaku bullying.

\begin{tabular}{|c|c|c|}
\hline Jenis bullying & Frekuensi (f) & Persentasi (\%) \\
\hline Fisik & 29 & 16,9 \\
\hline Verbal & 51 & 29,7 \\
\hline Nonverba langsung & 22 & 12,8 \\
\hline Nonverbal tidak langsung & 29 & 16,9 \\
\hline Total & 131 & 100 \\
\hline
\end{tabular}

Tabel 2. Distribusi frekuensi jumlah perilaku bullying berdasarkan jenis perilaku bullying. 


\begin{tabular}{|c|c|c|c|c|c|c|c|c|}
\hline \multirow{3}{*}{ Karakteristik } & \multicolumn{8}{|c|}{ Perilaku Bullying } \\
\hline & \multicolumn{2}{|c|}{ Rendah } & \multicolumn{2}{|c|}{ Sedang } & \multicolumn{2}{|c|}{ Tinggi } & \multicolumn{2}{|c|}{ Total } \\
\hline & $\mathbf{f}$ & $\%$ & $\mathbf{f}$ & $\%$ & $\mathbf{f}$ & $\%$ & $\mathbf{f}$ & $\%$ \\
\hline \multicolumn{9}{|l|}{ Usia } \\
\hline 15 & 10 & 91,9 & 1 & 9,1 & 0 & 0 & 11 & 100 \\
\hline 16 & 29 & 87,9 & 3 & 9,1 & 1 & 3 & 33 & 100 \\
\hline 17 & 37 & 100 & 0 & 0 & 0 & 0 & 37 & 100 \\
\hline 18 & 13 & 92,3 & 0 & 0 & 1 & 7,7 & 4 & 100 \\
\hline 19 & 3 & 100 & 0 & 0 & 0 & 0 & 13 & 100 \\
\hline 20 & 1 & 100 & 0 & 0 & 0 & 0 & 1 & 100 \\
\hline \multicolumn{9}{|l|}{ Jenis Kelamin } \\
\hline Laki-laki & 40 & 90,9 & 2 & 4,5 & 2 & 4,5 & 44 & 100 \\
\hline Perempuan & 52 & 96,3 & 2 & 3,7 & 0 & 0 & 54 & 100 \\
\hline \multicolumn{9}{|l|}{ Kelas } \\
\hline XI IPA & 20 & 100 & 0 & 0 & 0 & 0 & 20 & 100 \\
\hline XI IPS & 26 & 83,9 & 3 & 9,7 & 2 & 6,5 & 31 & 100 \\
\hline XII IPA & 34 & 100 & 0 & 0 & 0 & 0 & 34 & 100 \\
\hline XII IPS & 12 & 92,3 & 1 & 7,7 & 0 & 0 & 13 & 100 \\
\hline
\end{tabular}

Tabel 3. Distribusi frekuensi perilaku bullying berdasarkan karakteristik responden yaitu usia, jenis kelamin, kelas.

Tabel 1 menunjukkan bahwa sebagian besar perilaku bullying responden masuk dalam kategori tingkat rendah yaitu $92(93,9 \%)$ responden.

Berdasarkan tabel 2 diperoleh hasil bahwa jenis bullying yang paling sering dilakukan adalah bullying verbal dengan jumlah responden yang bullying verbalnya tinggi ialah 51 $(32,7 \%)$ responden, sedangkan jenis bullying yang paling sedikit dilakukan ialah bullying nonverbal langsung yakni $22(12,8 \%)$ responden. Pada penelitian ini ada beberapa responden yang memiliki jenis perilaku bullying yang tinggi lebih dari satu.

Tabel 3 menunjukkan nahwa semua responden dengan usia 1520 tahun memiliki tingkat perilaku bullying yang rendah. Perilaku bullyingnya rendah paling banyak pada responden dengan usia 17 tahun dengan jumlah 37 (100\%) responden.
Tingkat bullying sedang dominan pada usia 16 tahun yakni dengan jumlah responden 3 dan masingmasing satu orang dari responden dengan usia 16 dan 18 tahun yang perilaku bullyingnya tinggi.

Pada kategori jenis kelamin, tingkat perilaku bullying rendah pada perempuan lebih tinggi yakni 52 $(96,3 \%)$ responden, tingkat perilaku bullying yang sedang sama-sama terdapat 2 responden dari laki-laki dan perempuan, sedangkan tingkat perilaku bullying yang tinggi lebih cenderung dimiliki oleh laki-laki yakni $2(4,5 \%)$ responden.

Pada kategori kelas, semua kelas memiliki tingkat bullying yang rendah, tingkat perilaku bullying sedang paling banyak di kelas XI IPS dengan jumlah responden $3(9,7 \%)$ dan begitupun tingkat perilaku bullying yang tinggi terdapat pada $2(6,5 \%)$ di kelas XI IPS. 


\section{Gambaran tayangan televisi yang sering di tonton pada siswa kelas XI dan XII di SMA Maha Putra Makassar}

\begin{tabular}{lcc}
\hline & Frekuensi (f) & Persentasi (\%) \\
\hline Musik & 12 & 12,2 \\
Berita & 6 & 6,1 \\
Reality show & 2 & 2,0 \\
Infotainment & 5 & 5,1 \\
Competition show & 2 & 2,0 \\
Pertunjukan & 1 & 1,0 \\
Talk show & 6 & 6,1 \\
Variety show & 18 & 18,4 \\
Film & 9 & 9,2 \\
Sinetron & 21 & 21,4 \\
Kartun & 16 & 16,3 \\
\hline \multicolumn{1}{c}{ Total } & 98 & 100 \\
\hline
\end{tabular}

Tabel 4. Distribusi frekuensi program tayangan televisi yang sering ditonton oleh siswa kelas XI dan XII.

\begin{tabular}{lcc}
\hline & Frekuensi (f) & Persentasi (\%) \\
\hline Hiburan & 81 & 82,7 \\
Informasi & 17 & 17,3 \\
\hline \multicolumn{1}{c}{ Total } & 131 & 100 \\
\hline
\end{tabular}

Tabel 5. Distribusi frekuensi program tayangan televisi jenis hiburan dan informasi.

Berdasarkan tabel 4 menunjukkan bahwa program televisi yang paling banyak ditonton adalah jenis sinetron dengan jumlah $21(21,4$ $\%)$.

Berdasarkan tabel 5 menunjukkan bahwa jenis program televisi yang paling banyak ditonton adalah hiburan dengan jumlah 81 $(82,7 \%)$.

\section{B. Analisi Bivariat}

Analisi bivariat digunakan untuk melihat apakah terdapat hubungan tayangan televisi dengan perilaku bullying pada siswa kelas XI dan XII di SMA Maha Putra Makassar. Uji yang digunakan untuk melihat hubungan antar variabel independen dan dependen adalah uji Chi-Square.

\begin{tabular}{|c|c|c|c|c|c|c|c|}
\hline \multirow{3}{*}{ Program Televisi } & \multicolumn{6}{|c|}{ Perilaku Bullying } & \multirow{3}{*}{ Nilai $p$} \\
\hline & \multicolumn{2}{|c|}{ Rendah } & \multicolumn{2}{|c|}{ Sedang } & \multicolumn{2}{|c|}{ Rendah } & \\
\hline & $\mathrm{f}$ & $\%$ & $\mathrm{f}$ & $\%$ & $\mathrm{f}$ & $\%$ & \\
\hline Hiburan & 76 & 82,6 & 3 & 75 & 2 & 100 & 0747 \\
\hline Informasi & 16 & 17,4 & 1 & 25 & 0 & 0 & \\
\hline
\end{tabular}

Tabel 6. Hubungan program tayangan televisi yang sering ditonton dengan perilaku bullying pada siswa kelas XI dan XII di SMA Maha Putra Makassar.

Berdasarkan tabel 6 menunjukkan bahwa dengan menggunakan uji Chi-Square diperoleh nilai $\mathrm{p}=0,747$, nilai ini lebih besar daripada a $(0,05)$, hal tersebut menunjukkan bahwa tidak ada hubungan antara program televisi yang sering ditonton dengan perilaku bullying pada kelas XI dan XII.

\section{PEMBAHASAN}

1. Gambaran Perilaku Bullying pada Siswa Kelas XI dan XII di SMA Maha Putra Makassar

Tingkat perilaku bullying pada siswa kelas XI dan XII di SMA Maha Putra Makassar dominan rendah. Hal ini berarti kebanyakan 
responden memilih kategori jawaban 'jarang' pada kuesioner perilaku bullying, baik itu bullying fisik, verbal, nonverbal langsung atau nonverbal tidak langsung. Ada beberapa hal yang mempengaruhi tingkat perilaku bullying pada seseorang, seperti pada penelitian yang dilakukan oleh Saifullah (2014) yang menyatakan bahwa semakin tinggi (positif) konsep diri seorang remaja maka semakin rendah tingkat bullying yang dilakukan. Pada remaja pula, mereka telah mampu untuk membedakan hal yang baik dan buruk sebagaimana yang dikemukakan oleh Kartono (2014) bahwa remaja mulai melakukan perenungan terhadap pemikiran etis sehingga pada masa ini remaja dapat menemukan jati dirinya dan tahu apa yang ia lakukan.

Berdasarkan beberapa jenis perilaku bullying jenis yang paling banyak dilakukan berdasarkan hasil penelitian adalah bullying verbal. Dalam buku Sonneborn (2013) juga mengatakan bullying verbal adalah cara yang mudah, mereka mengandalkan kemampuan untuk mempermalukan dan melukai perasaan orang lain. Hal ini sejalan dengan hasil penelitian Karina, Hastuti, \& Alfiasan (2013) yang menunjukkan presentase terbesar bentuk bullying yang dilakukan remaja yang bersekolah di SMK Negeri maupun Swasta ialah bullying verbal.

Tingkat perilaku bullying yang tinggi paling tinggi ditunjukkan pada responden dengan usia 15 dan 18 tahun, hal tersebut dikarenakan pada rentang usia tersebut kemampuan mengambil tindakan belum sepenuhnya baik sebagaimana yang dikemukakan oleh Morgan (2014) bahwa kemampuan membuat keputusan belum sepenuhnya baik sampai pada usia pertengahan akhir dua puluhan. Sedangkan jenis kelamin yang perilaku bullyingnya tinggi ialah laki-laki, penelitian ini sejalan dengan Priyatna (2010) yang menyatakan bahwa pada anak laki-laki lebih sering mengalami bullying dan paling banyak juga lakilaki yang melakukan perilaku bullying dibandingkan dengan perempuan. Hal tersebut dapat terjadi karena siswa laki-laki di sekolah tersebut lebih sering melakukan perilaku bullying dari pada perempuan yang disebabkan oleh pengawasan orang tua kepada siswa laki-laki tersebut cenderung sedikit dan lebih condong pada kehidupan teman sebaya, seperti yang dikatakan oleh Gurian (2006) bahwa orang tua terlalu sedikit menghabiskan waktu dengan anak laki-laki dan condong ke kelompok sebayanya.

Tingkat perilaku bullying yang tinggi pula ditunjukkan oleh kelas XI IPS, hal tersebut sesuai dengan penuturan Guru BK di SMA Maha Putra bahwa siswa jurusan IPS di sekolah tersebut memiliki tingkat kenakalan yang lebih tinggi daripada jurusan IPA, dimana siswa IPA lebih dikenal dengan pola pikir yang serius dan pendiam sehingga mereka kurang interaksi dengan dunia luar, sedangkan siswa IPS lebih kreatif dan memiliki interaksi di luar yang sering. Hal tersebut sesuai dengan Fitrianingsih (2015) yang menyatakan bahwa anak IPA lebih menggunakan otak kiri yang menunjukkan orangnya serius, susah di ajak bercanda, susah bersosiaisasi dan pendiam. Sebaliknya, anak IPS menggunakann otak kanan yang lebih menggunakan kreativitas dan melihat dunia luar sehingga mudah bersosialisasi dan pergaulannya luas.

\section{Gambaran Tayangan Televisi yang Sering Ditonton oleh Siswa Kelas XI dan XII di SMA Maha Putra Makassar}

Berdasarkan hasil penelitian program tayangan televisi yang paling banyak ditonton adalah sinetron. Sinetron merupakan serial drama sandiwara yang ditayangkan secara bersambung (Adawiyah, 2014). Hasil tersebut sejalan dengan pendapat 
Takariani (2013) yang menyatakan bahwa dari berbagai program acara, sinetron paling banyak digemari mulai dari anak-anak hingga dewasa. Hal ini dikarenakan siswa di sekolah tersebut lebih suka menonton tayangan yang menghibur dan menyukai tontonan yang diperankan oleh remaja, hal tersebut diketahui melalui hasil wawancara dari beberapa responden saat penelitian berlangsung. Selain itu, lebih dari 50\% responden menyaksikan program yang sering mereka tonton sebanyak tujuh kali dalam seminggu atau dengan kata lain setiap hari dengan waktu yang berbeda-beda, mulai dari 30 menit hingga 6 jam setiap harinya.

\section{Hubungan Tayangan Televisi dengan Perilaku Bullying pada siswa kelas XI dan XII di SMA Maha Putra Makassar}

Berdasarkan hasil penelitian yang dilakukan, program tayangan televisi yang sering ditonton tidak memiliki hubungan dengan perilaku bullying yang dilakukan siswa kelas XI dan XII di SMA Maha Putra Makassar. Hasil penelitian ini bertentangan dengan hasil penelitian yang dilakukan oleh Malikhah (2013) yang menunjukkan bahwa ada hubungan yang siginifikan antara pengaruh tayangan televisi dengan perkembangan perilaku negatif anak di Taman Kanak-Kanak Aisyiyah Butanul Athfal. Hal tersebut karena banyak faktor yang dapat menyebabkan seseorang melakukan perilaku bullying diantaranya teman sebaya dan lingkungan, seperti hasil penelitian Priyantna (2010) dan Usman (2013) yang mengemukakan bahwa ada beberapa yang dapat mempengaruhi seseorang melakukan perilaku bullying, diantaranya pola asuh orang tua, suka bergaul dengan anak yang biasa melakukan bullying, pihak sekolah yang tidak menaruh perhatian pada tindakan bullying, pergaulan yang salah, iklim sekolah dan teman sebaya. Pada siswa SMA pun perilaku bullying banyak dipengaruhi oleh konformitas teman sebaya (Dewi, 2015). Hal tersebut dikarenakan remaja lebih cenderung mengadopsi nilai kelompok dan teman sebayanya (Usman, 2013). Ketika kelompoknya positif maka remaja akan cenderung memiliki kepribadian positif, begitupun sebaliknya, ketika kelompoknya negatif maka remaja tersebut cenderung memiliki kepribadian negatif. Oleh karena itu, ketika siswa SMA tersebut lebih banyak menghabiskan waktu dengan teman sebayanya dibanding frekuensi atau lama menonton televisi maka perilaku bullyingnya dapat lebih dipengaruhi oleh teman sebaya.

Program tayangan televisi lebih banyak mempengaruhi perilaku bullying pada anak usia dini dibandingkan dengan remaja, hal tersebut sejalan dengan penelitian Verlinden et al. (2014) yang menyatakan bahwa semakin sering anak terpapar televisi maka semakin tinggi perilaku bullying yang dilakukan dan penelitian Malikhah (2013) yang menunjukkan bahwa tayangan televisi memiliki hubungan yang signifikan terhadap perilaku negatif yang dilakukan oleh anak usia dini dikarenakan anak usia 2-7 tahun menyimpulkan sesuatu dari yang mereka lihat. Hal tersebut dikarenakan remaja telah mampu membedakan hal yang baik dan buruk serta dapat menentukan apa yang ia lakukan, sebagaimana Kartono (2014) mengemukakan bahwa remaja mulai menentukan nilai-nilai tertentu dan melakukan perenungan terhadap pemikiran etis sehingga pada masa ini remaja dapat menemukan jati dirinya dan tahu apa yang ia lakukan.

\section{KESIMPULAN}

Penelitian ini bertujuan untuk melihat adanya hubungan tayangan televisi dengan perilaku bullying pada siswa kelas XI dan XII di SMA Maha Putra Makassar. Hasil pada penelitian ini menunjukkan tidak adanya hubungan antara tayangan televisi dengan perilaku bullying yang 
dilakukan oleh siswa kelas XI dan XII di SMA Maha Putra Makassar. Dimana tingkat perilaku bullying dominan rendah, jenis bullying yang sering dilakukan ialah bullying verbal serta tayangan televisi yang paling banyak ditonton adalah sinetron.

\section{DAFTAR PUSTAKA}

Adawiyah, S. E. (2014). Sinetron dalam sudut pandang komunikasi islam. Jakarta: Universitas Muhammadiyah.

Astuti, E. S., \& Resminingsih. (2010). Bahan Dasar untuk PelayananKonseling pada Satuan Pendidikan Menengah Jakarta: Gradindo.

Dewi, C. K. (2015). Pengaruh konformitas teman sebaya terhadap perilaku bullying pada siswa SMA Negeri 1 Depok Yogyakarta. Jurnal Bimbingan dan Konseling, 1-12.

Fitrianingsih, A. (2015, Juni 17). Perbedaan cara berpikir anak IPA dan IPS. Retrieved November 28, 2016, from Kompasiana: http://www. kompasiana.com/am alia.fitrianingsih/ perbedaan-cara- berpikir-anak-ipa-danips_54f91a68a33311b6078b4624

Gurian, M. (2006). The wonder of boys. Jakarta: PT Serambi Ilmu Semesta.

Hamdi, I. (2016, April 15). KPAI: Kekerasan terhadap Anak Naik 15 Persen. Retrieved Agustus 23, 2016, from Tempo.Co: https://m.tempo.co/read/ news / 2016/04/15/063762948/kpaikekerasan-terhadap-anak-naik-15-persen

Hazliansyah. (2015, Desember 30). KPAI : Kasus Bullying di Sekolah Meningkat Selama 2015. Retrieved Agustus 23, 2016, from Republika.co.id: http://m. republika.co.id/berita/n asional/ umum/15/12/30/o067zt280-kpaikasus-bullying-di-sekolah-meningkatselama-2015

Karina, Hastuti, D., \& Alfiasan. (2013). Perilaku bullying dan karakter remaja serta kaitannya dengan karakteristik keluarga dan peer group. Jurnal Ilmu Keluarga \& Konseling, 20-29.

Kartono. (2014). Patologi sosial 2 kenakalan remaja.Jakarta: Rajawali Press

Komisi Perlindungan Anak Indonesia (KPAI). (2014, Oktober 16). KPAI: Kasus bullying dan pendidikan karakter. Retrieved September 25, 2016, from Komisi Perlindungan Anak Indonesia: www.kpai. go.id/berita/kpai- kasus-bullying-danpendidikan- karakter/

KPAI. (2016, Januari 20). KPAI : 'Quo vadis' perlindungan anak di sekolah : Antara norma dan realita. Retrieved September 25, 2016, from Komisi Perlindungan Anak Indonesia: www.kpai.go.id/berita/ kpai-quo- vadis-perlindungan-anak-di- sekolah-antara-norma-dan- realita/

KPI. (2015). Hasil survei indeks kualitas program siaran televisi.

Malikhah. (2013). Korelasi pengaruh tayangan televisi terhadap perkembangan perilaku negatif pada anak usia dini. [Skripsi Dipublikasikan]. Semarang: Universitas Negeri Semarang.

Morgan, N. (2014). Panduan mengatasi stress bagi remaja. Tangerang: Gemilang.

Nugraha, A. K. (2016, Mei 26). Berikut data kekerasan seksual padaanak 2015-2016. Retrieved Agustus 24, 2016, from Rakyatku News: http://news. rakyatku.com/read/6525/2016/05/26/ berikut-data-kekerasan-seksual-padaanak-2015-2016

Nurhayanti, R., Novotasari, D., \& Natalia. (2013). Tipe pola asuh orang tua yang berhubungan dengan perilaku bullying di SMA Kabupaten Semarang. Jurnal Keperawatan Jiwa, 49-59

Pambudhi, Y. A., \& Suroso, T. M. (2015). Efektivitas Group Cognitive Behavior Therapy (GCBT) dalam menurunkan kecemasan menghadapi perilaku bullying ditinjau dari harga diri pada

korban bullying. Jurnal Ilmiah Psikologi Terapan, 18-31.

Priyantna, A. (2010). Lets end bullying, memahami, mencegah \& mengatasi bullying. Jakarta: PT Elex Media Komputindo.

Rini, C. L. (2014, Oktober 23). Indonesia masuk kategori darurat bullying' di sekolah. Retrieved September 1, 2016, from News Republika.co.id: http://m. republika.co.id/berita/n asional/ umum/14/10/23/ndvn63-indonesiamasuk-kategori- darurat-bullying-disekolah

Saifullah, F. (2014). Hubungan antara konsep diri dengan perilaku bullying pada siswa siswi SMP. eJournal Psikologi, 200-214.

Sherwood, L. (2013). Fisiologi manusia dari sel ke sistem, edisi 6.Jakarta: EGC.

Sonneborn, L. (2013). How to beat verbal bullying. New York: The Rosen Publishing Group.

Supartini, Y. (2004). Buku ajar konsep dasar keperawatan anak. Jakarta: EGC.

Takariani, C. S. (2013). Pengaruh sinetron remaja di televisi swasta terhadap sikap mengenai gaya hidup hedonis. Jurnal Penelitian Komunikasi, 39-54.

Usman, I. (2013). Kepribadian, Komunikasi, Kelompok Teman Sebaya, Iklim Sekolah dan Perilaku Bullying. Humanitas, Vol. X No. 1, 49-60.

Verlinden, M., \& all, e. (2014). Television viewing trought age $2-5$ years and bullying involvement in early elementary school. BMC Public Health, 1-13. 